\title{
Оптимальний розподіл інвестицій у групі взаємопов'язаних підприємств вугільної галузі
}

\begin{abstract}
У статті запропоновано новий підхід щсодо розподілу інвестицій у групі підприємств з видобутку вугілля. Вперше запропоновано модель оцінки виробничої ефективності підприємств як похідну від рівня залучених ресурсів до кількості продукиії, при иььму основним критерієм $\epsilon$ ефективність вилучення запасів. Дослідження зміни запасів (в даному випадку вугілля) у часі дозволяє спрогнозувати техніко-економічні показники підприємства у довгостроковій перспективі. В роботі розв'язано актуальну науково-практичну задачу, яка полягає у дослідженні впливу інвестищій на приріст продуктивності вугільних шахт. Авторами запропоновано для вирішення проблеми перерозподілу коштів між підприємствами, щзо займаються видобутком ідентичної продукиії застосувати критерій «економічна надійність». На основі оцінки економічної надійності робиться загальний висновок про те, який обсяг інвестицій слід залучити для збільшення видобутку, при цььому розглядаються усі підприємства. Практична иінність роботи полягає у встановленні залежності рівня приросту видобутку від залучених інвестицій для підприємств з різним рівнем економічної надійності. Встановлено, щяо найефективніший варіант трансформаиї шахт вуглепромислового регіону - це компенсації можливого зниження обсягів видобутку, при изьому необхідний їх приріст за рахунок додаткового навантаження найефективніших діючих шахт $i$, як правило, з меншими капітальними витратами. Все иче підтверджує високу доцільність створення надійних методів ранжування шахт. Виконані розрахунки оптимальних значень потужності шахт свідчать про потенційні можливості шахт Державної вугільної компанії (ДВК), які забезпечені значними запасами та мають достатньо високий рівень економічної надійності. Використання динамічного підходу до вибору параметрів трансформації шахт до беззбиткового режиму дозволяє скоротити витрати підприєства та забезпечити його сталий розвиток шляхом своєчасного впровадження нових інвестиційних проектів з урахуванням оптимального терміну експлуатаиії иахти.
\end{abstract}

Ключові слова: вугільні шахти; вуглепромисловий регіон; беззбитковість; моделювання; диверсифікація; потенціал; запаси.

Актуальність теми. Особливості системи управління вугільними шахтами на сучасному етапі тісно пов'язані зі зміною стратегічних орієнтирів у їхній діяльності. Основними економічними цілями підприємства в ринкових умовах є підвищення ефективності виробництва на основі управління внутрішніми резервами. Найважливішу роль у виконанні завдань, що стоять перед галуззю, відіграє політика відмови від бюджетної підтримки збиткових вугледобувних підприємств за рахунок управління їх потенціалом. У даному контексті це можливість видобутку певного обсягу вугілля і можливість їі нарощування, досягнення беззбитковості і забезпечення певного рівня рентабельності, зниження рівня дотацій і створення умов інвестиційної привабливості та ін. Факти свідчать, що в умовах державної підтримки збиткових шахт так і не був приведений до дії механізм зниження виробничих витрат. Для галузі залишається важливим питання про рівень витрат на видобуток. Досить висока собівартість свідчить про низьку ефективність роботи вугільної шахти, незалежно від того, викликано це природними чинниками або незадовільним рівнем управління. Разом з тим, висока собівартість може слугувати лише сигналом про доцільність закриття шахти, на підставі однієї лише високої собівартості це питання не може бути вирішене. Пояснюється це тим, що шахта є досить складною системою, яка не може бути вичерпно охарактеризована будь-яким одним показником. Тому необхідно вирішити проблему оптимального розподілу інвестицій між підприємствами в межах виробничого об'єднання, вугільної компанії та ін.

Аналіз останніх досліджень та публікації, на які спирається автор. Проблема розподілу інвестицій між підприємствами вугільної галузі розглянута у роботах О.І. Амоші [1], Д.Ю. Череватського [2], В.Г. Гріньова [3], А.О. Хорольського [4]. За кордоном проблемами залучення інвестицій у вугледобувний комплекс займалися: M.Nieć [5], C.Cyrnek [6], M.Krzak [7], B.Balusa [8], P.Li [9], M. Beaulieu [10]. Зокрема в роботі [4] зазначено, що для підвищення ефективності виробництва необхідно збалансувати 
потоки вхідних та вихідних ресурсів залежно від сценарію виробництва. На основі ретроспективного аналізу стану галузі [11] авторами зроблено припущення, що наразі без залучення інвестицій галузь неможливо вивести із кризового стану. При цьому подальше зволікання призведе до стагнації, переходу від «стабільного занепаду» до неконтрольованого згортання виробничих потужностей, тому необхідно відповісти на ряд питань: Як розподілити кошти між підприємствами? Яким критерієм слід керуватись при розподілі капіталовкладень? Яку політику слід виробити до групи підприємств в рамках галузі? Вирішенню цих питань присвячено дане дослідження.

Метою статті є дослідження закономірностей зміни росту приросту видобутку від залучення інвестицій з урахуванням рівня економічної надійності вугільного підприємства, що дозволило розробити підхід з визначення рівня інвестицій для групи шахт в межах однієї юридичної особи.

Викладення основного матеріалу. Завдання знаходження оптимального варіанту спеціалізації взаємопов'язаних підприємств має ряд спільних рис з завданням визначення оптимального розміщення виробничого комплексу, в якій здійснюється вибір найкращого розміщення місць будівництва нових підприємств (поряд з визначенням розмірів їх виробничих потужностей) та вибір варіантів збереження і розширення діючих підприємств. В обох випадках доводиться враховувати виробничі витрати i обмеження. Фактичними змінними в тих і інших завданнях є обсяги виробництва товарної вугільної продукції та різних видів продукції диверсифікації, а також схеми збуту цієї продукції в пунктах споживання. I в тому випадку, якщо для існуючих і перспективних виробничих потужностей можливі різні варіанти їх спеціалізації, то має сенс розглядати єдину математичну задачу, що включає в себе проблеми спеціалізації, кооперування і комбінування. Для математичних постановок задач цього типу характерні нелінійність витрат залежно від обсягів виробництва, наявність локально-оптимальних рішень, вимоги цілочисельності ряду невідомих і необхідність аналізу впливу зміни ряду параметрів. Останнє призводить до параметричного та стохастичного програмування $[12,13]$. Задача спеціалізації взаємопов'язаних виробництв, що не включає проблеми розміщення нових потужностей, $є$ типовою задачею поточного планування, при якому виробничі потужності шахт можна вважати заданими. Завдання ж, пов'язані 3 розміщенням нових виробництв (наприклад, 3 переробки відходів шахт i збагачувальних фабрик), є задачею перспективного планування. Але оскільки період поточного планування є невід’ємною частиною періоду перспективного планування, особливості задач спеціалізації виявляються цілком властивими і завданням управління конкретним підприємством конкретного вуглепромислового регіону $[14,15]$.

Припустимо, що група взаємопов'язаних шахт характеризується деяким об'ємом товарної вугільної продукції, і ця продукція може вироблятися тільки на певній кількості підприємств. Відомо, що нормативи витрат на одиницю продукції змінюються залежно від обсягу іiі виробництва. Однак на збиткових вугільних підприємствах, оснащених ненадійним очисним обладнанням, виробничі витрати при прийнятій технології і інтенсивності, як правило, помітно не змінюються залежно від того, які саме комплекси машин і в якій кількості зайняті видобуванням вугілля [16]. Неодмінною умовою для виявлення різних напрямів підвищення ефективності вуглевидобутку і приросту потужності є кількісна оцінка стану окремих технологічних ланок, що визначають виробничу потужність шахти. Оцінка може здійснюватися за допомогою сукупності наведених показників, причому питомі показники можуть бути розраховані як на одиницю видобутих запасів, так і на одиницю річного обсягу видобутку вугілля. При цьому справедливе співвідношення

$$
\begin{aligned}
& P_{j z}=\frac{\sum_{t} P_{j t}}{Z}=\frac{\sum_{t} P_{j D t} D_{t}}{\sum D_{t}} \\
& P_{j D t}=\frac{P_{j t}}{D_{t}},
\end{aligned}
$$

де $P_{j z}-j$-й питомий показник в розрахунку на одиницю запасів; $P_{j t}-j$-й абсолютний показник в $t$-му році роботи шахти; $Z$ - запаси, які добуваються за весь термін служби шахти (горизонту); $P_{j D t}-j$-й питомий показник в розрахунку на одиницю видобутку в $t$-му році; $D_{t}$ - обсяг видобутку вугілля в шахті (горизонту) в $t$-му році.

У той же час для того щоб виключити з розгляду якомога більше проміжних виробничих стадій, зручно виразити витрати предметів праці, які надходять на підприємство ззовні, і витрати первинних ресурсів через лінійну функцію кінцевого («товарного») випуску цього підприємства. Для цього, крім лінійної залежності витрат від обсягу видобутку (переробки) на всіх стадіях, необхідно, щоб підприємство не отримувало з боку продукцію, яку воно може виробляти само [16]. Тому в умови побудови моделі доцільно ввести в розгляд поряд 3 поняттям «підприємство» поняття «виробничої одиниці». Під нею розуміється підприємство, група ділянок, для яких можна вважати виконуваними такі умови: 
1) якщо виробнича одиниця може випускати продукцію даного виду, то вона не отримує іiі ззовні;

2) технологічні нормативи витрат на одиницю продукції даного виду не змінюються залежно від зміни обсягу виробництва або розподілу цієї продукції по обладнанню виробничої одиниці. За змістом даного визначення підприємство, на якому, наприклад, будь-яка наступна стадія виробництва може бути забезпечена сировиною з попередньої стадії лише частково, а недолік покривається ввезенням з боку, не може вважатися виробничою одиницею, а є їх сукупністю.

У такому визначенні виробничої одиниці полягає одна 3 відмінностей постановки справжнього завдання від внутрішньовиробничих задач лінійного програмування на найкраще використання обладнання. Без введення цього поняття пропонована задача перетворилася б в задачу спеціалізації для окремих шахт або ділянок шахтних полів даної групи підприємств. Невідомими такої задачі, що пов'язані безпосередньо з окремими виробничими одиницями, є кількість продукції $i$-го виду, вироблена для поставки в інші регіони країни.

Найпростішим способом визначення показників трансформації (у даному випадку це приріст потужності залежно від рівня інвестиційних коштів) може з'явитися виявлення однорідних груп шахт i визначення для них витрат на приріст кожної тонни виробничої потужності, виходячи із залежності капітальних вкладень від гірничо-геологічних чинників, що впливають на них. Проте внаслідок дуже складного і сумісного впливу природних чинників на капітальні вкладення при реструктуризації шахт дати кількісну оцінку впливу кожного з них в чистому вигляді практично неможливо. Це в свою чергу не дає можливості за великої різноманітності природних умов родовищ і окремих ділянок скласти однорідні групи.

Аналіз кошторисної вартості модернізації шахт різної потужності на одній і тій же гірничогеологічній ділянці дозволив встановити, що відповідні інвестиції умовно можна розділити на три частини: що змінюються прямо пропорційно потужності шахт; що змінюються, але 3 деяким відставанням від зростання потужності і практично не залежні від потужності шахти. При цьому від потужності шахти залежать витрати на удосконалення загальношахтних ланок. Вказані принципи модернізації можна виразити функцією $\varphi_{i}(X)=\overline{1, n-1}$, яка визначає максимальний приріст потужності шахт за відповідних розподілів $X$ інвестицій між $i$ шахтами. Тому значення функції $\varphi_{n}(X)$ обчислюється лише для значення $X=S$, оскільки обсяг інвестицій, що виділяються для всіх $n$ шахт, рівний $S$.

Нами було досліджено вплив рівня інвестицій на приріст потужності. На основі динамічного моделювання [17-19] вихідних даних (табл. 1) було побудовано залежності зміни приросту продуктивності від залучених коштів для трьох державних шахт (рис. 1).

Таблиия 1

Вихідні дані динамічного моделювання приросту потужності шахт ДП «Державна вугільна компанія»

\begin{tabular}{|c|c|c|c|}
\hline \multirow{2}{*}{$\begin{array}{c}\text { Обсяг інвестицій, } \\
X_{i} \text { (млн грн) }\end{array}$} & \multicolumn{3}{|c|}{ Приріст потужності шахт $f\left(X_{i}\right)$ залежно від обсягу інвестицій } \\
\cline { 2 - 4 } & $\begin{array}{c}\text { «Південно- } \\
\text { донбаська» № 3 }\end{array}$ & $\begin{array}{c}\text { «Південно- } \\
\text { донбаська» № } 1\end{array}$ & «Капітальна» \\
\hline 50 & 86,8 & 1,6 & 24,2 \\
\hline 100 & 222,6 & 99,3 & 221,9 \\
\hline 150 & 302,1 & 156,5 & 273,7 \\
\hline 200 & 358,5 & 197,1 & 313,9 \\
\hline 250 & 402,2 & 228,5 & 346,7 \\
\hline 300 & 437,9 & 254,2 & 374,4 \\
\hline 350 & 468,2 & 276,0 & 398,5 \\
\hline 400 & 494,3 & 294,8 & 419,7 \\
\hline 450 & 517,4 & 311,4 & 438,6 \\
\hline 500 & 538,1 & 326,3 & 455,8 \\
\hline 550 & 556,7 & 339,7 & 471,4 \\
\hline 600 & 573,8 & 352,0 & \\
\hline
\end{tabular}

Нами пропонується спрощений підхід до визначення шляхів перерозподілу інвестицій залежно від рівня економічної надійності шахт. Задача формулюється таким чином. Для збільшення обсягів видобутку вугілля шахтам виділено капіталовкладення обсягом $S$ млнгрн. Використання $i$-м підприємством $x_{i}$ млн грн з вказаних коштів забезпечує приріст видобутку, що визначається значенням нелінійної функції $f_{i}\left(X_{i}\right)$. Необхідно знайти розподіл капіталовкладень між шахтами, який забезпечуватиме максимальне збільшення випуску готової вугільної продукції. Таким чином, може бути узагальнене положення 3 точки зору моделювання напрямів реструктуризації шахт перед тим, як диверсифікація гірничодобувних регіонів стане процесом, що є добре спланованим і керованим у часі [20]. 
Доведено європейським досвідом, що поспішне, непродумане закриття замикаючих шахт не може бути визнане розумним, зважаючи на необхідність компенсації потужностей, які вибувають, імпортними енергоносіями $[21,22]$.

Рисунок 1 свідчить про те, що кожне підприємство реагує на інвестиції залежно від стану гірничого господарства, гірничо-геологічних умов залягання та технології відпрацювання запасів. Це пояснюється тим, що для кожного підприємства існує окремий рівень економічної надійності, який визначиться за формулою:

$$
K_{e H}=K_{m t} \times K_{e t}+K_{c t}
$$

де $K_{e н t}$ - показник економічної надійності шахти в момент або за період $t ; K_{m t}-$ коефіцієнт технологічної надійності на момент $t$; $\mathrm{K}_{e t}$ - коефіцієнт економічного рівня на момент $t ; K_{2 t}$ - показник рівня запасів, що залишилися в момент $t$.

Техніко-економічне значення показника економічної надійності полягає в тому, що він представляє комплексну оцінку шахти за сукупністю іiі технічного рівня і економічних результатів функціонування. Ця обставина має важливе практичне значення. Якщо визначити показники економічної надійності для шахт регіону, то можна отримати об'єктивну картину стану шахтного фонду. При цьому буде отримана кількісна оцінка, тому що часто використовуються тільки експертні суб'єктивні або емоційні оцінки. Наявність об'єктивних і комплексних оцінок дозволяє обгрунтовано підійти до вирішення питань черговості приватизації шахт.

Зокрема, шахта «Капітальна», що має показник економічної надійності вище за шахти «Південнодонбаська № 3» та «Південнодонбаська № 1», більш дієво забезпечує приріст потужності.

На основі закономірностей, встановлених нами (рис. 1) та залежно від рівня економічної надійності шахт, приступаємо до знаходження розв'язку задачі перерозподілу 600 млн грн, що передбачається планами розвитку ДП «Державна вугільна компанія» для завершення реконструкції шахт «Південодонбаська № 1», «Південодонбаська № 3» та «Капітальна», тобто до визначення спочатку умовно оптимальних, а потім і оптимальних розподілів інвестицій між підприємствами.

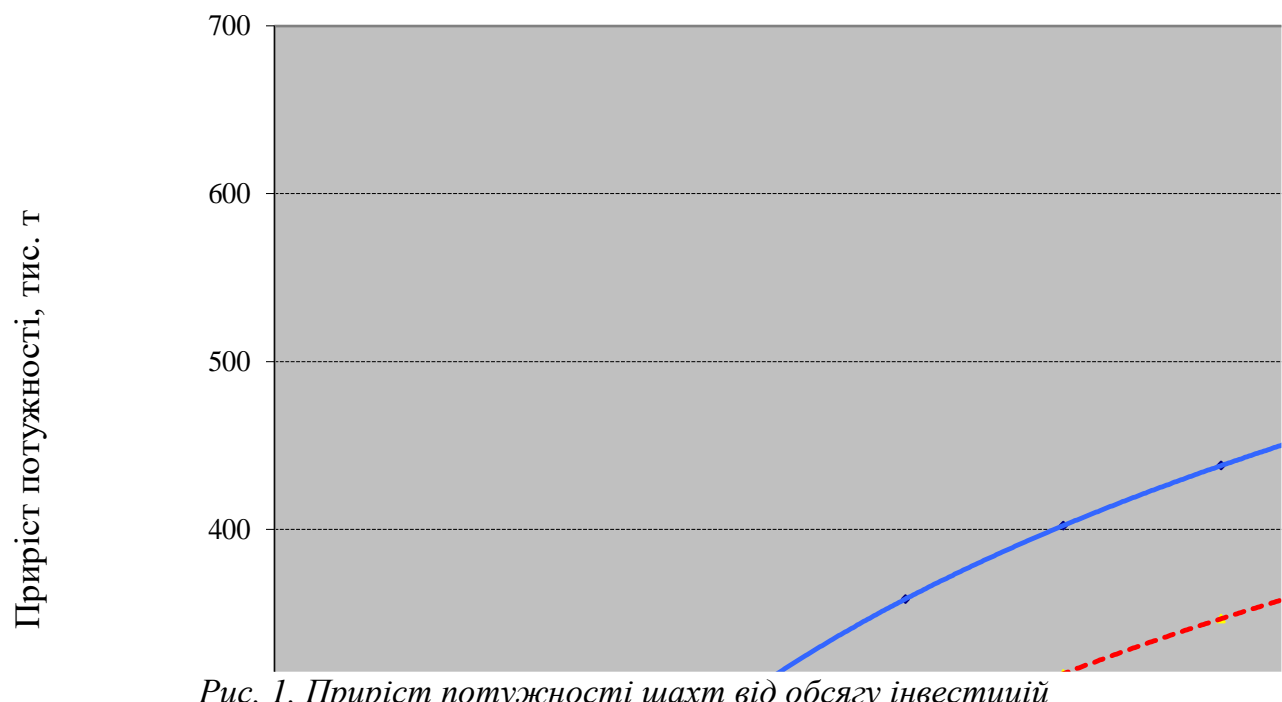

За іншими варіантами реструктуризації шахти (шахт) сума капітальних вкладень на гірничі роботи визначається, виходячи з розрахованої величини капітальних вкладень на гірничі роботи у відсотках від потужності шахти. Обсяг капітальних вкладень на гірничі роботи у відсотках росте зі збільшенням потужності шахт.

Таким чином, розв’язання даної задачі динамічного програмування доцільно починати з визначення оптимального рішення на останньому, $n$-м кроці, тобто для однієї шахти. Для того, щоб знайти цей розв'язок, очевидно, потрібно зробити різні припущення про те, як може закінчитися передостанній крок, і з урахуванням цього вибрати управління, що забезпечує максимальне значення функції $W_{n}\left(X^{(n-1)}, u_{n}\right)$. Таке управління, вибране при певних припущеннях про те, як закінчився попередній крок, називається умовно оптимальним управлінням. Отже, принцип оптимальності вимагає знаходити на кожному кроці умовно оптимальне управління для будь-якого з можливих результатів попереднього кроку.

Згідно з визначеним алгоритмом на першому кроці розглядаються можливості інвестування шахти «Південнодонбаська № 1», а далі - розподіл коштів між шахтами «Південнодонбаська № 3 » 
«Капітальна». Переходимо тепер до розрахунку значень, використовуючи для цього відповідні дані попередніх розрахунків.

$$
\varphi_{3}(X)=\max \left\{f_{3}\left(X_{3}\right)+\varphi_{2}\left(X-X_{3}\right)\right\} .
$$

Розрахунки доводять, що максимальний приріст потужності цих трьох шахт може дорівнювати 829,2 тис. т на умовах розподілу інвестицій у пропорції 200 млн грн кожній шахті протягом періоду реконструкції тривалістю 6 років. У таблиці 2 наведено дані про приріст потужності шахти «Капітальна».

Таблиия 2

Умовно-оптимальний обсяг інвестииій для шахти «Капітальна»

\begin{tabular}{|c|c|c|}
\hline $\begin{array}{c}\text { Обсяг інвестицій } \mathrm{X}_{\mathrm{i}}, \\
(\text { млн грн) }\end{array}$ & $\begin{array}{c}\text { Максимальний приріст } \varphi_{2} \\
(\mathrm{X}) \text { потужності, тис. т }\end{array}$ & $\begin{array}{c}\text { Умовно-оптимальний обсяг } \\
\text { інвестицій, для шахти «Капітальна», } \\
\text { млн грн }\end{array}$ \\
\hline 100 & 222,6 & 0 \\
\hline 200 & 358,5 & 0 \\
\hline 300 & 457,8 & 100 \\
\hline 400 & 555,5 & 200 \\
\hline 500 & 635,0 & 300 \\
\hline 600 & 692,2 & 300 \\
\hline
\end{tabular}

Виконані розрахунки оптимальних значень потужності шахт свідчать про потенційні можливості шахт Державної вугільної компанії (ДВК), які забезпечені значними запасами та мають достатньо високий рівень економічної надійності.

Висновки та перспективи подальших досліджень. У процесі виконання дослідження було встановлено, що рівень кінцевого прибутку залежить не тільки від рівня механізації, організації роботи на підприємстві, але і від якості освоєння запасів, які є на балансі. Для вирішення проблеми ефективного розподілу коштів між групами підприємств в межах однієї юридичної особи слід застосувати комплексну оцінку за параметром «економічна надійність», що враховує якість освоєння запасів та рівень концентрації робіт. Встановлено, що найефективніший варіант трансформації шахт вуглепромислового регіону - це компенсації можливого зниження обсягів видобутку, необхідний їх приріст за рахунок додаткового навантаження найефективніших діючих шахт i, як правило, 3 меншими капітальними витратами.

Подальші дослідження слід спрямувати на дослідження зв'язків між підприємствами в циклі генерації енергії, металу, що дозволить стабілізувати ситуацію у промислових регіонах. Для цього необхідно буде розробити моделі динамічного програмування, що дозволять відслідкувати зміну запасів у часі в ланцюжках «вугілля-кокс-метал» та «вугілля-збагачувальні фабрики-електроенергія».

\section{Список використаної літератури:}

1. Амоша А.И. Инновационное развитие промышленных предприятий в регионах: проблемы и перспективы А.И. Амоша, Л.Н. Соломатина // Экономика Украины. - 2017. - № 3. - С. 20-34.

2. Череватский Д.Ю. Об экстернальной экономике угледобывающих гетерархий / Д.Ю. Череватский // Экономика промышленности. - 2018. - № 4 (84). - С. 72-86.

3. Гринев В.Г. Инновационные перспективы эксплуатации угольных пластов крутого падения / В.Г. Гринев, П.В. Череповский, А.И. Деуленко. - Днепропетровск : Пороги, 2015. - 180 с.

4. Хорольский А.А. Использование динамического программирования для проектирования горного производства при ограниченных ресурсах / А.А. Хорольский, В.Г. Гринев // Информационные технологии в образовании, науке и производстве : VI Международная научно-техническая интернет-конференция. 2018. - C. 17-18.

5. Nieć M. Występowanie rud uranu i perspektywy ich poszukiwań w Polsce / M.Nieć // Polityka energetyczna. 2009. - T. 12. - C. 435-451.

6. Zabierowski J. Methods for scientific investigations in programming in the mining industry / J.Zabierowski, A.Jaskowski, C.Cyrnek // Pr. Kom. Gorn. Geod. Gorn. - 1981. - Vol. 21. - P. 39-47.

7. Krzak M. The Evaluation Of An Ore Deposit Development Prospect Through Application Of The «Games Against Nature» Approach / M.Krzak // Asia-Pacific Journal of Operational Research. - 2013. - T. 30. - № 06.

8. Balusa B.C. Underground mining method selection using WPM and PROMETHEE / B.C. Balusa, J.Singam // Journal of the Institution of Engineers (India): Series D. - 2018. - T. 99. - № 1. - P. 165-171.

9. Li P. Time series prediction of mining subsidence based on a SVM / P.Li et al. // Mining Science and Technology (China). - 2011. - T. 21. - № 4. - C. 557-562.

10. Beaulieu $M$. An enumeration algorithm for solving the fleet management problem in underground mines / M.Beaulieu, M.Gamache // Computers \& Operations research. - 2006. - T. 33. - № 6. - C. 1606-1624. 
11. Хорольський А.О. Інноваційні перспективи підземної експлуатації вугільних родовищ / А.О. Хорольський, В.Г. Гріньов, О.Р. Мамайкін // Вісник Житомирського державного технологічного університету / Серія : Технічні науки. - 2019. - № 83. - С. 289-298.

12. Dimitrakopoulos $R$. Stochastic integer programming for optimising long term production schedules of open pit mines: methods, application and value of stochastic solutions / R.Dimitrakopoulos, S.Ramazan // Mining Technology. - 2008. - T. 117. - № 4. - C. 155-160.

13. Hrinov $V$. Improving the process of coal extraction based on the parameter optimization of mining equipment / V.Hrinov, A.Khorolskyi // E3S Web of Conferences. - EDP Sciences, 2018. - T. 60. - C. 00017.

14. Models and methods to make decisions while mining production scheduling / A.Khorolskyi, V.Hrinov, O.Mamaikin, Yu.Demchenko // Mining of Mineral Deposits. - 2019. - Vol. 13 (4). - P. 53-62.

15. Coal industry in the context of Ukraine economic security / O.Mamaikin, J.Kicki, S.Salli, V.Horbatova // Mining of Mineral Deposits / National Mining University. - Dnepr, 2017. - Vol. 11. - P. 17-22.

16. Morin M.A. Underground mine design and planning: complexities and interdependencies. Mineral Resources / M.A. Morin. - 2002. - P. 197-215.

17. Решение горных задач на ЭВМ при освоении рудных месторождений / В.Г. Гринев, В.П. Зубков, В.Ю. Изаксон, С.П. Шкулев. - Новосибирск : Наука ; Сиб. издат. фирма РАН, 1999. - 257 с.

18. Ashcheulova A. Factors of corporate social responsibility in Ukraine. A role of the EU in its development / V.Shapoval, A.Ashcheulova // Zeszyty Naukowe Wyzszej Szkoly Bankowej we Wrocławiu. - 2010. - № 15. P. 229-240.

19. Ashcheulova A. Ecologic Component of Social Responsibility of Business (Experience of Poland and Ukraine) / V.Shapoval, A.Ashcheulova // Common Europe: Ukraine and Poland under Conditions of Globalization and European Integration : Monograph ; ed. K.Wilk, A.Hetmanczuk. - Poznan-Wrocław : Wydawnictwo Wyzszej Szkoły Bankowej, 2012. - 399 p

20. Brazil M. Cost optimisation for underground mining networks / M.Brazil et al. // Optimization and engineering. 2005. - T. 6. - № 2. - C. 241-256.

21. Liu $Q$. Effectiveness research on the multi-player evolutionary game of coal-mine safety regulation in China based on system dynamics / Q.Liu, X.Li, X.Meng // Safety science. - 2019. - T. 111. - C. 224-233.

22. Musingwini C. Technical operating flexibility in the analysis of mine layouts and schedules / C.Musingwini, R.C.A. Minnitt, M.Woodhall // Journal of the Southern African Institute of Mining and Metallurgy. - 2007. T. 107. - № 2. - C. 129-136.

\section{References:}

1. Amosha, A.I. and Solomatina, L.N. (2017), «Innovacionnoe razvitie promyshlennyh predprijatij v regionah: problemy i perspektivy», Ekonomika Ukrainy, Vol. 3, pp. 20-34.

2. Cherevatskij, D.Ju. (2018), «Ob jeksternal'noj jekonomike ugledobyvajushhih geterarhij», Ekonomika promyshlennosti, Vol. 4 (84), pp. 72-86.

3. Grinev, V.G., Cherepovskij, P.V. and Deulenko, A.I. (2015), Innovacionnye perspektivy jekspluatacii ugol'nyh plastov krutogo padenija, Porogi, Dnepropetrovsk, $180 \mathrm{p}$.

4. Horol'skij, A.A. and Grinev, V.G. (2018), «Ispol'zovanie dinamicheskogo programmirovanija dlja proektirovanija gornogo proizvodstva pri ogranichennyh resursah», Informacionnye tehnologii v obrazovanii, nauke i proizvodstve, pp. $17-18$

5. Nieć, M. (2009), «Występowanie rud uranu i perspektywy ich poszukiwań w Polsce», Polityka energetyczna, Vol. 12, pp. 435-451.

6. Zabierowski, J., Jaskowski, A. and Cyrnek, C. (1981), «Methods for scientific investigations in programming in the mining industry», Pr. Kom. Gorn. Geod. Gorn, Vol. 21, pp. 39-47.

7. Krzak, M. (2013), «The Evaluation Of An Ore Deposit Development Prospect Through Application Of The" Games Against Nature" Approach», Asia-Pacific Journal of Operational Research, Vol. 30 (6).

8. Balusa, B.C. and Singam, J. (2018), «Underground mining method selection using WPM and PROMETHEE», Journal of the Institution of Engineers (India), Series D., Vol. 99 (1), pp. 165-171.

9. Li P. et al. (2011), "Time series prediction of mining subsidence based on a SVM», Mining Science and Technology (China), Vol. 11 (4), pp. 557-562.

10. Beaulieu, M. and Gamache, M. (2006), «An enumeration algorithm for solving the fleet management problem in underground mines», Computers \& Operations research, Vol. 33 (6), pp. 1606-1624.

11. Khorolskyi, A.O., Hrinov, V.H. and Mamaikin, O.R. (2019), «Innovatsiini perspektyvy pidzemnoi ekspluatatsii vuhilnykh rodovyshch», Visnyk Zhytomyrskoho derzhavnoho tekhnolohichnoho universytetu, Seriia Tekhnichni nauky, Vol. 83, pp. 289-298.

12. Dimitrakopoulos, R. and Ramazan, S. (2008), «Stochastic integer programming for optimising long term production schedules of open pit mines: methods, application and value of stochastic solutions», Mining Technology, Vol. 117 (4), pp. 155-160.

13. Hrinov, V.G. and Khorolskyi, A.A. (2018), «Improving the Process of Coal Extraction Based on the Parameter Optimization of Mining Equipment», E3S Web of Conferences, Ukrainian School of Mining Engineering, Vol. 60, pp. $1-10$.

14. Khorolskyi, A., Hrinov, V., Mamaikin, O. and Demchenko, Yu. (2019), «Models and methods to make decisions while mining production scheduling», Mining of Mineral Deposits, Vol. 13 (4), pp. 53-62.

15. Mamaikin, O., Kicki, J., Salli, S. and Horbatova, V. (2017), «Coal industry in the context of Ukraine economic security», Mining of Mineral Deposits, Vol. 11, pp. 17-22. 
16. Morin, M.A. (2002), «Underground mine design and planning: complexities and interdependencies», Mineral Resources, pp. 197-215.

17. Grinev, V.G., Zubkov, V.P., Izakson, V.Yu. and Shkulev, S.P. (1999), «Reshenie gornyh zadach na EVM pri osvoenii rudnyh mestorozhdenij», Nauka, Novosibirsk.

18. Ashcheulova, A. and Shapoval, V. (2010), «Factors of corporate social responsibility in Ukraine. A role of the EU in its development», Zeszyty Naukowe Wyzszej Szkoly Bankowej we Wrocławi, Vol. 15, pp. 229-240.

19. Ashcheulova, A. and Shapoval, V. (2012), «Ecologic Component of Social Responsibility of Business (Experience of Poland and Ukraine)», Common Europe: Ukraine and Poland under Conditions of Globalization and European Integration, Wydawnictwo Wyzszej Szkoły Bankowej, 399 p.

20. Brazil, M. et al. (2005), «Cost optimisation for underground mining networks», Optimization and engineering, Vol. 6 (2), pp. 241-256.

21. Liu, Q., Li, X. and Meng, X. (2019), «Effectiveness research on the multi-player evolutionary game of coal-mine safety regulation in China based on system dynamics», Safety science, Vol. 111, pp. 224-233.

22. Musingwini, C., Minnitt, R.C.A. and Woodhall, M. (2007), «Technical operating flexibility in the analysis of mine layouts and schedules», Journal of the Southern African Institute of Mining and Metallurgy, Vol. 107 (2), pp. 129-136.

Ащеулова Олександра Миколаївна - кандидат економічних наук, доцент Національного технічного університету «Дніпровська політехніка».

https://orcid.org/0000-0002-2137-0516.

Наукові інтереси:

- обліково-аналітичне забезпечення сталого розвитку вугільних підприємств.

E-mail: ashcheulova_an@ukr.net.

Демченко Юрій Іванович - кандидат технічних наук, доцент Національного технічного університету «Дніпровська політехніка».

https://orcid.org/0000-0001-7486-1266.

Наукові інтереси:

- оптимізація параметрів експлуатації родовищ корисних копалин;

- $\quad$ розробка наукових підходів для керування процесами зміни стану родовищ;

- оцінка інноваційних перспектив родовищ.

E-mail: dem.yu@nmu.org.ua.

Прихорчук Олександр Іванович - головний інженер ШУ «Першотравенське» ПрАТ ДТЕК «Павлоградвугілля».

https://orcid.org/0000-0002-0591-2178.

Наукові інтереси:

- оптимізація параметрів експлуатації родовищ корисних копалин;

- розробка наукових підходів для керування процесами зміни стану родовищ;

- управління виробництвом;

- менеджмент енергомеханічної служби.

E-mail: mamaykin@yahoo.com.

Мамайкін Олександр Рюрікович - кандидат технічних наук, доцент Національного технічного університету «Дніпровська політехніка».

https://orcid.org/0000-0002-2137-0516.

Наукові інтереси:

- оптимізація параметрів експлуатації родовищ корисних копалин;

-

- оцінка інноваційних перспектив родовищ.

E-mail: alex.mamaikin80@gmail.com. 